\title{
THE LEVEL OF UNDERSTANDING OF PEDAGOGICAL COMPETENCE OF PHYSICAL EDUCATION, HEALTH AND RECREATION STUDENTS OF SPORTS SCIENCE FACULTY
}

\author{
Tri Ani Hastuti ${ }^{1 \mathrm{ABCDE}}$, Herka Maya Jatmika ${ }^{1 \mathrm{ABCDE}}$, \\ Kukuh Wahyudin Pratama ${ }^{2 B C D E}$, Dewangga Yudhistira ${ }^{2 B C D E}$ \\ ${ }^{1}$ Yogyakarta State University \\ ${ }^{2}$ Institute of Advanced Science, Engineering, and Education (IASEE)
}

Authors' Contribution: A - Study design; B - Data collection; C - Statistical analysis; D - Manuscript Preparation; E - Funds Collection

Corresponding Author: Tri Ani Hastuti,E-mail: tri_anihastuti@uny.ac.id

Accepted for Publication: October 16, 2021

Published: December 25, 2021

DOI: 10.17309/tmfv.2021.4.04

\begin{abstract}
The study purpose. This study aims to determine the level of understanding of the pedagogical competence of Physical Education, Health and Recreation students of the Faculty of Sports Science, Yogyakarta State University, batch 2016.

Materials and methods. This research method is a survey with a quantitative descriptive approach. The population is 180 physical education students, the sample selection is 52 physical education students using incidental sampling technique. The research instrument is a valid and reliable questionnaire. The data analysis technique is the analysis presented using the percentage.

Results. The results obtained show that the level of understanding of the pedagogic competence of Physical Education, Health and Recreation students of the Faculty of Sports Science, Yogyakarta State University, class 2016 was "very low" 3.85\% (2 students), "low" 67.31\% (35 students), "medium" 19.23\% (10 students), "high" 9.62\% (5 students) and "very high" $0 \%$ (0 students).

Conclusions. Based on the results of the study, it can be concluded that the level of understanding of the pedagogic competence of Physical Education students is in the low category.

Keywords: level of understanding, pedagogical competence, physical education, health and recreation students.
\end{abstract}

\section{Introduction}

Education is an effort that is made consciously and intentionally to change human behavior both individually and in groups to become mature humans through teaching and training (Gaetano, 2012). Talking about education, of course, cannot be separated from learning and teaching activities, one of the efforts to realize educational expectations requires a teacher.

The teacher is an educator whose job is to guide, direct, teach, train, assess, educate and evaluate students through formal education (Yusnita et al., 2018; Azhary, Handoyo, \& Khafid, 2018). As a competent educator, of course, he wants to make a good contribution to the progress of his students (Asari, Fauziyah, \& Uchtiawati, 2018; Ahmad \& Setyaningsih, 2012). The ability to manage and manage learning and

(C) Hastuti, T. A., Jatmika, H. M., Pratama, K. W., \& Yudhistira, D., 2021. teaching activities in education is called pedagogic competence (Asari, Fauziyah, \& Uchtiawati, 2018).

In particular, pedagogic competencies can be classified as follows: (a) personality is not innate but professional roles developed through tiered training (Liakopoulou, 2011), (b) deepening and mastery of material to save time and teach more important knowledge by referring to research data that refers to the chosen strategy (Beyer, 2002; Oser et al., 2006), (c) special abilities and skills that have an effective impact on teaching practice (Liakopoulou, 2011), (d) attitudes towards teaching and learning activities that are not only able to evaluate, understand and choose knowledge, but how to use and act (Liakopoulou, 2011).

Based on this description, the author states that pedagogic competence is very complex. Therefore, there is a need for a more in-depth study. One of the educational universities in Indonesia, namely Yogyakarta State University, must organize several programs synergistically, including 
academic and professional education programs in the field of education (Physical Education, Health and Recreation Curriculum 2014, 2015: 4). The realization of educational institutions, especially the faculty of sports science, cannot be separated from educational programs and curriculum implementation through courses.

Courses have objectives in accordance with the fields of knowledge and skills that are limited by the curriculum. Students of the Physical Education, Health, and Recreation study program who take the Physical Education Teacher Professional Preparation course can be said to have understood the professionalism and competence as a physical education teacher in accordance with the Book of Competency Standards for Beginner Teachers of the Bachelor of Physical Education Study Program.

Based on a preliminary study through observations and interviews with Physical Education students at the time of introduction to the school field, problems were found related to understanding teacher competencies, especially pedagogic competencies, these problems were: (1) some students still had difficulties in designing learning, so the design of learning practices was still copy paste to friends and the internet, this is a problem because the conditions of one school are different from one another, (2) some students teach not in accordance with the lesson plans that have been prepared, this of course can hinder students in developing their talents and potential, (c) in evaluating In learning, some students make assessments based on subjectivity, for example giving good marks to students who have been recognized (d) besides that there are students who have not been able to understand student characteristics, such as difficulties in managing students who do not want to take part in learning $\mathrm{n}$ in class.

Based on the investigation of several research literature on this topic, it has often been done, but in particular there are differences in the problems and variables that exist, thus the purpose of this study is to find out and describe the level of understanding of the pedagogic competence of students in Physical Education, Health and Recreation, Faculty of Sports Science, State University Yogyakarta batch 2016.

\section{Materials and methods}

\section{Study participants}

This research method is descriptive quantitative, which describes the variables studied (Atmowardoyo, 2018). The inclusion criteria in this study were students of physical education, health and recreation class 2016 who were taking field introduction courses at school, then the exclusion criteria were students did not collaborate with researchers. The population is 180 students while the sample is 52 students. The sampling technique is incidental sampling (Ward et al., 2018).

\section{Study organization}

The instrument in this study uses the test method (Assarroudi, 2018). The data collection technique was observation using a questionnaire instrument, before being used the instrument was checked by experts and then tested for validity and reliability. The data used is primary data, which is taken from participants in the field. The data collection mechanism is as follows: (1) Researchers seek data from students of Physical Education, Health and Recreation, Faculty of Sports Science, State University of Yogyakarta batch 2016 who have taken the Field School Introduction course. (2) Researchers determine the number of students who are the subject of research. (3) Researchers distribute instruments in the form of multiple choice tests. (4) The researcher collected the test results and transcribed the results of filling out the test. (5) After that, the data is tabulated and percentage. To find out whether the item is good or not, it is done by analyzing the item using the formula: Difficulty $\mathrm{P}=\mathrm{R} / \mathrm{T}$. Information: $\mathrm{R}=$ the number of respondents who answered each item correctly. $\mathrm{T}=$ number of respondents who answered the test.

Table 1. Difficulty Level Criteria

\begin{tabular}{cl}
\hline Difficulty Index & \multicolumn{1}{c}{ Information } \\
\hline Less than 0.30 & Items in the difficult category \\
$0.31-0.70$ & Items in the Sufficient category \\
More thsn 0.71 & Easy categorized question items \\
\hline
\end{tabular}

(Source: Arikunto, 2013:210)

A test can be said to be good if the alternative answers chosen are at least $5 \%$ of all respondents who work on the question. Validity test is used to analyze each question item with the help of the product moment correlation formula.

Table 2. Criteria for the Level of Distinguishing Power for the Item Problem

\begin{tabular}{cl}
\hline $\begin{array}{c}\text { Item } \\
\text { Distinguishing } \\
\text { Power }\end{array}$ & \multicolumn{1}{c}{ Information } \\
\hline $0-0.20$ & Question items have weak distinguishing power \\
$0.21-0.40$ & $\begin{array}{l}\text { Question items have moderate distinguishing } \\
\text { power }\end{array}$ \\
$0.41-0.70$ & $\begin{array}{l}\text { Question items have good distinguishing power } \\
0.71-1.00\end{array}$ \\
& $\begin{array}{l}\text { Question items have very strong distinguishing } \\
\text { power }\end{array}$ \\
Signed Negative & $\begin{array}{l}\text { The question item has very bad distinguishing } \\
\text { power }\end{array}$ \\
\hline
\end{tabular}

(Source: Arikunto. 2013: 210)

\section{Statistical analysis}

The data analysis technique in this study uses percentage data analysis, which will present statistical descriptive data including tables, graphs, diagrams, circles, pictograms, mean, median, mode, percentile, decile calculation, standard deviation and percentage (Deeks et al., 2019). The calculation is assisted by SPSS 25 , then to clarify the analysis process, categorization will be carried out. Categorization consists of very high, high, medium, low, very low. The research basis for determining this ability is to maintain a level of consistency in research, with the following formula (Hox et al., 2017): $\mathrm{P}=\mathrm{F} / \mathrm{N} \quad 100 \%$. Information: $\mathrm{P}=$ Percentage sought, $\mathrm{F}=$ Frequency, $\mathrm{N}=$ Number of Respondents. 
Determine the interval using the formula from Arikunto (2013: 207) in table 3 as follows:

Table 3. Assessment Norms

\begin{tabular}{lcc}
\hline No & Interval & Category \\
\hline 1 & $81-100$ & Very High \\
2 & $61-80$ & High \\
3 & $41-60$ & Medium \\
4 & $21-40$ & Low \\
5 & $0-20$ & Very Low
\end{tabular}

(Source: Arikunto, 2013: 207)

\section{Results}

The results of this study aim to describe the level of understanding of pedagogic competence, with the following results: the lowest score (minimum) 12.82, the highest score (maximum) 89.76, the average (average) 37.8, the average score mean (median) 35.89, frequency (mode) 23.07, standard deviation (SD) 16.68 .

Table 4. Results of Student Pedagogical Competence Comprehension

\begin{tabular}{clccr}
\hline No & Interval & Category & Frequency & $\%$ \\
\hline 1 & $81-100$ & Very High & 0 & $0.00 \%$ \\
2 & $61-80$ & High & 5 & $9.61 \%$ \\
3 & $41-60$ & Medium & 10 & $19.23 \%$ \\
4 & $21-40$ & Low & 35 & $67.31 \%$ \\
5 & $0-20$ & Very Low & 2 & $3.85 \%$ \\
Total & & 52 & $100.00 \%$ \\
\hline
\end{tabular}

Based on table 4, it is explained that the level of understanding of pedagogic competence is in the "very low" category of $3.85 \%$ (2 students), "low" of $67.31 \%$ (35 students), "Medium" of 19.23\% (10 students), "high" 9.61\% (5 students) and "very high" $0 \%$ (0 students). Based on these results, the dominant category is included in the low category, the following diagram is presented:

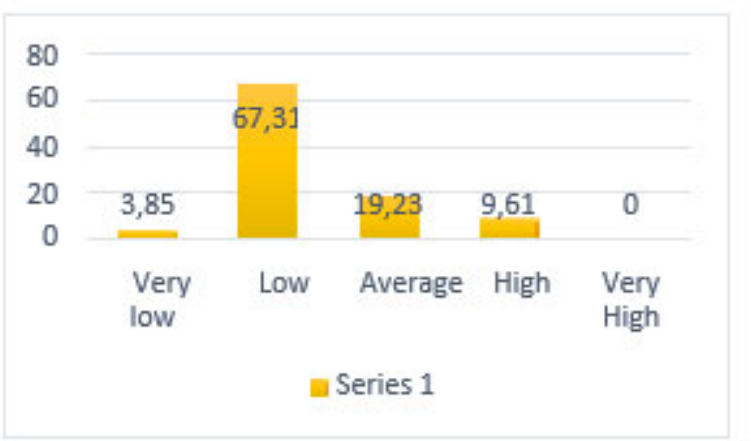

Fig. 1. Bar diagram of the level of understanding of the pedagogic competence

\section{Mastery Factor Characteristics of Students}

Based on table 5, the results show that the characteristic completeness factor is in the very low category $5.77 \%$ (3 students), low at $30.77 \%$, moderate at $40.38 \%$ (21 students), high 19.23\% (10 students ) and "very high 3.85\% (2 students). The most dominant category in the mastery factor of student characteristics is in the "medium" category.

Table 5. Results of Study of Student Characteristics Mastery Factors

\begin{tabular}{ccccc}
\hline No & Interval & Category & Frequency & $\%$ \\
\hline 1 & $81-100$ & Very High & 2 & $3.85 \%$ \\
2 & $61-80$ & High & 10 & $19.23 \%$ \\
3 & $41-60$ & Medium & 21 & $40.38 \%$ \\
4 & $21-40$ & Low & 16 & $30.77 \%$ \\
5 & $0-20$ & Very Low & 3 & $5.77 \%$ \\
Total & & & 52 & $100.00 \%$ \\
\hline
\end{tabular}

\section{Factor Theory and Principles of Learning}

Based on table 6, it was found that the factors of learning theory and learning principles were in the "very low" category of $25.00 \%$ (13 students), "low" of $46.15 \%$ (24 students), "medium" of $0.00 \%$ (0 students), "high" $23.08 \%$ (12 students) and "very high" 5.77\% (3 students). The most dominant category of learning theory factors and learning principles is in the "low" category.

Table 6. Research Results of Learning Theory Factors and Learning Principles

\begin{tabular}{ccccc}
\hline No & Interval & Category & Frequency & \multicolumn{1}{c}{$\%$} \\
\hline 1 & $81-100$ & Very High & 3 & $5.77 \%$ \\
2 & $61-80$ & High & 12 & $23.08 \%$ \\
3 & $41-60$ & Medium & 0 & $0.00 \%$ \\
4 & $21-40$ & Low & 24 & $46.15 \%$ \\
5 & $0-20$ & Very Low & 13 & $25.00 \%$ \\
Total & & & 52 & $100.00 \%$ \\
\hline
\end{tabular}

\section{Curriculum Development Factors}

Based on table 7, it was found data that the curriculum development factor was in the "very low" category of 5.77\% (3 students), "low" of 19.23\% (10 students), "medium" of $57.69 \%$ (30 students), "high" 9.62\% (5 students) and "very high" $7.69 \%$ (4 students). The most dominant category in the curriculum development factor is the "medium" category.

Table 7. Research Results of Curriculum Development Factors

\begin{tabular}{ccccc}
\hline No & Interval & Category & Frequency & $\%$ \\
\hline 1 & $81-100$ & Very High & 4 & $7.69 \%$ \\
2 & $61-80$ & High & 5 & $9.62 \%$ \\
3 & $41-60$ & Medium & 30 & $57.69 \%$ \\
4 & $21-40$ & Low & 10 & $19.23 \%$ \\
5 & $0-20$ & Very Low & 3 & $5.77 \%$ \\
Total & & & 52 & $100.00 \%$ \\
\hline
\end{tabular}




\section{Educating Learning Factors}

Based on table 8, it was found that the educational learning factors were in the "very low" category of 21.15\% (11 students), "low" of $26.92 \%$ (14 students), "medium" of $25 \%$ (13 students), "high" 13.46\% (7 students) and "very high" $13.46 \%$ ( 7 students). The most dominant category in educational learning factors is in the "low" category.

Table 8. Research Results of Educating Learning Factors

\begin{tabular}{ccccc}
\hline No & Interval & Category & Frequency & $\%$ \\
\hline 1 & $81-100$ & Very High & 7 & $13.46 \%$ \\
2 & $61-80$ & High & 7 & $13.46 \%$ \\
3 & $41-60$ & Medium & 13 & $25.00 \%$ \\
4 & $21-40$ & Low & 14 & $26.92 \%$ \\
5 & $0-20$ & Very Low & 11 & $21.15 \%$ \\
Total & & & 52 & $100.00 \%$ \\
\hline
\end{tabular}

\section{Information and Communication Technology Utilization Factors}

Based on table 9 it is found that the use of information and communication technology is in the "very low" category of $16.46 \%$ (7 students), "low" of $0.00 \%$ (0 students), "medium" of $38.46 \%$ ( 20 students), "high" $0.00 \%$ (0 students) and "very high" $48.08 \%$ (25 students). The most dominant category on technology, information and communication factors is in the "high" category.

Table 9. Research Results on Information and Communication Technology Utilization Factors

\begin{tabular}{ccccc}
\hline No & Interval & Category & Frequency & $\%$ \\
\hline 1 & $81-100$ & Very High & 25 & $48.08 \%$ \\
2 & $61-80$ & High & 0 & $0.00 \%$ \\
3 & $41-60$ & Medium & 20 & $38.46 \%$ \\
4 & $21-40$ & Low & 0 & $0.00 \%$ \\
5 & $0-20$ & Very Low & 7 & $13.46 \%$ \\
Total & & & 52 & $100.00 \%$ \\
\hline
\end{tabular}

\section{Student Potential Development Factors}

Based on table 10, it was found that the data on the potential development factors of students were in the "very low" category of $61.54 \%$ (32 students), "low" of $0.00 \%$ (0 students), "medium" of $32.69 \%$ (17 student). students), "high" 0.00\% (0 students) and "very high" 5.77\% (3 students). The most dominant category in the development of student potential is in the "very low" category.

Table 10. Research Results of Students' Potential Development Factors

\begin{tabular}{ccccc}
\hline No & Interval & Category & Frequency & $\%$ \\
\hline 1 & $81-100$ & Very High & 3 & $5.77 \%$ \\
2 & $61-80$ & High & 0 & $0.00 \%$ \\
3 & $41-60$ & Medium & 17 & $32.69 \%$ \\
4 & $21-40$ & Low & 0 & $0.00 \%$ \\
5 & $0-20$ & Very Low & 32 & $61.54 \%$ \\
Total & & & 52 & $100.00 \%$ \\
\hline
\end{tabular}

\section{Effective, Empathic, and Polite Communication Factors}

Based on table 11, it was found that the effective, empathic and polite communication factors were in the "very low" category of $61.54 \%$ (32 students), "low" of $0.00 \%$ (0 students), "medium" of $28,85 \%$ (15 students), "high" 0.00\% (0 students) and "very high" 9.61\% (5 students). The most dominant category on effective, empathetic and polite communication factors is in the "very low" category.

Table 11. Research Results of Effective, Empathic and Polite Communication Factors

\begin{tabular}{ccccc}
\hline No & Interval & Category & Frequency & $\%$ \\
\hline 1 & $81-100$ & Very High & 5 & $9.61 \%$ \\
2 & $61-80$ & High & 0 & $0.00 \%$ \\
3 & $41-60$ & Medium & 15 & $28.85 \%$ \\
4 & $21-40$ & Low & 0 & $0.00 \%$ \\
5 & $0-20$ & Very Low & 32 & $61.54 \%$ \\
Total & & & 52 & $100.00 \%$ \\
\hline
\end{tabular}

Factors for Assessment and Evaluation of Learning Process and Outcomes

Based on table 12, it has been found that the assessment and evaluation factors of learning processes and outcomes are in the "very low" category of $67.31 \%$ (35 students), "low" of $17.31 \%$ (9 students), "medium". of 9, 61\% (5 students), "high" 0.00\% (0 students) and "very high" 5.77\% (3 students). The most dominant category in the assessment and evaluation process factors as well as learning outcomes are in the "very low" category.

Table 12. Research Results of Assessment and Evaluation Process and Learning Outcomes

\begin{tabular}{ccccc}
\hline No & Interval & Category & Frequency & $\%$ \\
\hline 1 & $81-100$ & Very High & 3 & $5.77 \%$ \\
2 & $61-80$ & High & 0 & $0.00 \%$ \\
3 & $41-60$ & Medium & 5 & $9.61 \%$ \\
4 & $21-40$ & Low & 9 & $17.31 \%$ \\
5 & $0-20$ & Very Low & 35 & $67.31 \%$ \\
Total & & & 52 & $100.00 \%$ \\
\hline
\end{tabular}

\section{Evaluation Factors for Learning Purposes}

Based on table 13, it was found that the evaluation factor for the benefits of learning was in the "very low" category of $44.23 \%$ (23 students), "low" of $34.62 \%$ (18 students), "medium" of $0 \%$ (0 students), "high" $13.46 \%$ (7 students) and "very high" $7.69 \%$ (4 students). The most dominant category in the evaluation factor for learning purposes is in the "very low" category.

Table 13. Research Results of Evaluation Factors for Learning Interests

\begin{tabular}{ccccc}
\hline No & Interval & Category & Frequency & \multicolumn{1}{c}{$\%$} \\
\hline 1 & $81-100$ & Very High & 4 & $7.69 \%$ \\
2 & $61-80$ & High & 7 & $13.46 \%$ \\
3 & $41-60$ & Medium & 0 & $0.00 \%$ \\
4 & $21-40$ & Low & 18 & $34.62 \%$ \\
5 & $0-20$ & Very Low & 23 & $44.23 \%$ \\
Total & & & 52 & $100.00 \%$ \\
\hline
\end{tabular}




\section{Reflective Action Factors for Improved Learning}

Based on table 14, it was found that the reflective action factor for improving the quality of learning was in the "very low" category of $28.85 \%$ (15 students), "low" of $38.46 \%$ (20 students), "medium" of 0\% (0 students), "high" 26.92\% (14 students) and "very high" 5.77\% (3 students). The most dominant category in the reflective action factor for improving the quality of learning is in the "low" category.

Table 14. Results of Reflective Action Research for Improved Learning

\begin{tabular}{ccccc}
\hline No & Interval & Category & Frequency & $\%$ \\
\hline 1 & $81-100$ & Very High & 3 & $5.77 \%$ \\
2 & $61-80$ & High & 14 & $26.92 \%$ \\
3 & $41-60$ & Medium & 0 & $0.00 \%$ \\
4 & $21-40$ & Low & 20 & $38.46 \%$ \\
5 & $0-20$ & Very Low & 15 & $28.85 \%$ \\
Total & & & 52 & $100.00 \%$ \\
\hline
\end{tabular}

\section{Discussion}

Based on the results of the study, it shows that the level of understanding pedagogical competence Physical Education Health and Recreation Students, Faculty of Sport Sciences, Yogyakarta State University, batch 2016, the most dominant category is in the low category. The low category indicates that the level of understanding of the pedagogic competence of the Physical Education Health and Recreation Student Faculty of Sport Sciences, Yogyakarta State University, batch 2016 has not met the expectations of the faculty and the Competency Standards Regulation of the Minister of National Education No. 16 of 2007 concerning Teacher Qualification and Competency Standards as teacher candidates explaining that teachers are good if they meet competencies the main aspects of which are pedagogical competencies that must be possessed by teachers. The results in the low category are also due to the fact that the respondents have difficulty working on the test questions.

Similar to previous research, it was explained that other difficulties experienced by participants recorded through this study were related to the question model (Höglinger \& Diekmann, 2017). This is reinforced by Koo and Li (2016), questions about model descriptions with illustrations frankly make us confused, sometimes for us the relationship between statements and questions is difficult to understand. Based on the factor of the level of understanding pedagogical competence Physical Education Health and Recreation students, Faculty of Sport Sciences, Yogyakarta State University, batch 2016 is described as follows: The level of understanding pedagogical competence Physical Education Health and Recreation students, Faculty of Sport Sciences, Yogyakarta State University, batch 2016 based on the mastery factor of student characteristics, the most dominant category is in the "average" category. A teacher must master the characteristics of students because by understanding and approaching students the teacher can easily provide learning to students and can develop the potential that students have. The teacher has an understanding of the psychology of child development so that he knows exactly the right approach to take on his students. Teachers can guide children through difficult times in the ages experienced by students. In addition, the teacher has knowledge and understanding of the child's personal background so that they can identify problems faced by students and determine appropriate solutions and approaches. According to Standards Regulation of the Minister of National Education No. 16 of 2007, there are 6 aspects, namely physical, intellectual, socio-emotional, moral, spiritual, and sociocultural background.

The level of understanding pedagogical competence Physical Education Health and Recreation students, Faculty of Sport Sciences, Yogyakarta State University, batch 2016 is based on the learning theory and learning principles, the most dominant category is in the "low" category. Mastering several learning theories will enrich the methods used by the teacher, making it easier for teachers to form several variations of learning that can increase student motivation.

The level of understanding pedagogical competence Physical Education Health and Recreation students, Faculty of Sport Sciences, Yogyakarta State University, batch 2016 based on curriculum development factors, the most dominant category is in the "average" category. By understanding the curriculum, the teacher can teach directed and focused with the material presented not to deviate from the material to be delivered.

The level of understanding pedagogical competence Physical Education Health and Recreation students, Faculty of Sport Sciences, Yogyakarta State University, batch 2016 is based on educational learning factors, the most dominant category is in the "very low" category. The implementation of educational and dialogical learning, with the teacher carrying out learning that educates the teacher, can create an atmosphere of activity in the classroom and in the field by using multi methods and teaching techniques in learning. According to Amin et al. (2020) technically the implementation of learning activities shows in several things, namely the management of learning places / classrooms, management of learning materials, managing activities and time, managing students, managing learning resources and managing teaching behavior.

The level of understanding pedagogical competence Physical Education Health and Recreation students, Faculty of Sport Sciences, Yogyakarta State University, batch 2016 based on the use of technology, information and communication factors, the most dominant category is in the "high" category. The use of learning technology by utilizing teacher learning technology can be creative and can develop children's potential. In organizing the learning, teachers are using technology as a medium. Providing learning materials and administration using information technology. Familiarize children with interacting using technology. Based on a literature review, it is stated that the use of technology in education and learning (e-learning) provides convenience or makes learning effective for students. This means that teachers are required to prepare and present material on a computer network system that can be accessed by students. Therefore, teachers and prospective teachers are equipped with various competencies related to the use of information and communication technology as learning technology (Hashim, 2018).

The level of understanding pedagogical competency Physical Education Health and Recreation students, Faculty of Sport Sciences, Yogyakarta State University, batch 2016 based on the development factors of potential students, the most dominant category is in the category of "low". The development of students to actualize the various potentials they have, the teacher 
must know the potential of the child so that the teacher can develop the potential that the child has. Teachers have the ability to guide children, create a place for children to recognize their potential and train them to actualize their potential.

The level of understanding pedagogical competency Physical Education Health and Recreation students, Faculty of Sport Sciences, Yogyakarta State University, batch 2016 is based on communication factors that are effective, empathic and polite, the most dominant category is in the "low" category. Effective communication is the key to the success of the lessons to be conveyed. Meanwhile, empathic and polite elements can make communication continuity more meaningful.

The level of understanding pedagogical competency Physical Education Health and Recreation students, Faculty of Sport Sciences, Yogyakarta State University, batch 2016 based on the assessment and evaluation of learning outcomes, the most dominant category is in the "low" category. Assessment and evaluation of learning outcomes, by evaluating teacher learning, can determine the level of children's learning completion and to improve the quality of learning programs in general.

The level of understanding pedagogical competency Physical Education Health and Recreation students, Faculty of Sport Sciences, Yogyakarta State University, batch 2016 is based on the assessment and evaluation results for learning purposes, the most dominant category is in the "low" category. The results of the assessment and evaluation are an effort to improve the quality of the process and learning outcomes.

The level of understanding pedagogical competency Physical Education Health and Recreation students, Faculty of Sport Sciences, Yogyakarta State University, batch 2016 is based on reflective action factors to improve the quality of learning, the most dominant category is in the "low" category. Reflection on learning should be seen as part of the professional performance of the teacher to improve his competence as an educator. In learning reflection, the teacher can choose any technique that allows him to contemplate the learning that he has given and when doing so does not feel like a burden.

Although researchers have tried hard to meet all the requirements required, this does not mean that this research is without weaknesses and shortcomings. Some of the weaknesses and shortcomings that can be stated in this study include: (1) The difficulty of knowing the respondent's seriousness in taking the test. Efforts were made to minimize errors, namely by providing an overview of the aims and objectives of this study. (2) Data collection in this study was only based on the results of filling out the test so that there was an element of less objective in filling the test. In addition, in the filling of tests obtained the nature of the respondent himself such as honesty and fear in answering the question in fact. (3) When collecting research data, namely when distributing research instruments to respondents, it cannot be monitored directly and carefully whether the answer given by the respondent is really in accordance with his opinion or not.

\section{Conclusions}

Based on the results and discussion, it was concluded that the level of understanding of students' pedagogic competence was in the "very low" category of 3.85\% (2 students), "low" of $67.31 \%$ (35 students), "Medium" of 19.23\% (10 students), "high" 9.62\% (5 students) and "very high" 0\% (0 students).

\section{Acknowledgement}

The author would like to thank the Yogyakarta State University and the 2016 Physical Health and Recreational Education Students who have helped and provided support in this research.

\section{Conflict of interest}

All authors declare that there is no conflict of interest

\section{References}

Gaetano, R. (2012). Motor learning and didactics into physical education and sport documents in middle school-first cycle of education in Italy. Journal of physical education and sport, 12(2), 157.

Yusnita, Y., Eriyanti, F., Engkizar, E., Anwar, F., Putri, N. E., Arifin, Z., \& Syafril, S. (2018). The Effect of Professional Education and Training for Teachers (PLPG) in Improving Pedagogic Competence and Teacher Performance. Tadris: Jurnal Keguruan dan Ilmu Tarbiyah, 3(2), 123. https://doi.org/10.24042/tadris.v3i2.2701

Azhary, L., Handoyo, E., \& Khafid, M. (2018). The Implementation of Integrated Character Education in Policy Design at SD Muhammadiyah (Plus) Salatiga. Journal of Primary Education, 7(2), 172-178.

Asari, S., Fauziyah, N., \& Uchtiawati, S. (2018). Improving Teacher Pedagogic Competences in Remote Areas through Lesson Study Activity. International Journal of Education and Literacy Studies, 6(2), 53. https://doi.org/10.7575/aiac.ijels.v.6n.2p.53

Ahmad, A., \& Setyaningsih, E. (2012). Teacher Professionalism: A Study on Teachers' Professional and Pedagogic Competence at Junior, Senior, and Vocational High Schools in Banyumas Regency, Central Java, Indonesia. Sosiohumanika, 5(1).

Liakopoulou, M. (2011). Teachers' Pedagogical Competence as a Prerequisite for Entering the Profession: European Journal of Education, Part I. European Journal of Education, 46(4), 474-488. https://doi.org/10.1111/j.1465-3435.2011.01495.x

Beyer, L. E. (2002). The Politics of Standards and the Education of Teachers. Teaching Education, 13(3), 305316. https://doi.org/10.1080/1047621022000023280

Oser, F. K., Achtenhagen, F., \& Renold, U. (2006). Competence Oriented Teacher Training: Old Research Demands and New Pathways. BRILL. https://doi.org/10.1163/9789087903374

Atmowardoyo, H. (2018). Research Methods in TEFL Studies: Descriptive Research, Case Study, Error Analysis, and R \& D. Journal of Language Teaching and Research, 9(1), 197. https://doi.org/10.17507/jltr.0901.25

Ward, J. K., Comer, U., \& Stone, S. (2018). On Qualifying Qualitative Research: Emerging Perspectives and the "Deer" (Descriptive, Exploratory, Evolutionary, Repeat) Paradigm. Interchange, 49(1), 133-146. https://doi.org/10.1007/s10780-018-9313-x

Assarroudi, A., Heshmati Nabavi, F., Armat, M. R., Ebadi, A., \& Vaismoradi, M. (2018). Directed qualitative content analysis: The description and elaboration of its underpinning methods and data analysis process. Journal of Research in Nursing, 23(1), 42-55. https://doi.org/10.1177/1744987117741667 
Deeks, J. J., Higgins, J. P., Altman, D. G., \& on behalf of the Cochrane Statistical Methods Group. (2019). Analysing data and undertaking meta-analyses. Wiley. https://doi.org/10.1002/9781119536604.ch10

Hox, J. J., Moerbeek, M., \& van de Schoot, R. (2017). Multilevel Analysis: Techniques and Applications. Routledge. https://doi.org/10.4324/9781315650982

Höglinger, M., \& Diekmann, A. (2017). Uncovering a Blind Spot in Sensitive Question Research: False Positives Undermine the Crosswise-Model RRT. Political Analysis, 25(1), 131-137. https://doi.org/10.1017/pan.2016.5

Koo, T. K., \& Li, M. Y. (2016). A Guideline of Selecting and Reporting Intraclass Correlation Coefficients for
Reliability Research. Journal of Chiropractic Medicine, 15(2), 155-163. https://doi.org/10.1016/j.jcm.2016.02.012

Amin, A. M., Corebima, A. D., Zubaidah, S., \& Mahanal, S. (2020). The Correlation between Metacognitive Skills and Critical Thinking Skills at the Implementation of Four Different Learning Strategies in Animal Physiology Lectures. European Journal of Educational Research, 9(1), 143-163.

Hashim, H. (2018). Application of technology in the digital era education. International Journal of Research in Counseling and Education, 2(1), 1-5.

Arikunto, Suharsimi (2013). Prosedur Penelitian Suatu Pendekatan Praktik. Jakarta: Rineka Cipta.

\title{
РІВЕНЬ РОЗУМІННЯ ПЕДАГОГІЧНОЇ КОМПЕТЕНТНОСТІ СТУДЕНТІВ ФАКУЛЬТЕТУ СПОРТИВНИХ НАУК, ЯКІ СПЕЦІАЛІЗУЮТЬСЯ НА ФІЗИЧНОМУ ВИХОВАННІ, ОЗДОРОВЛЕННІ ТА РЕКРЕАЦІЇ
}

\author{
Три Ані Хастуті ${ }^{1 \mathrm{ABCDE}}$, Герка Майя Ятміка ${ }^{1 \mathrm{ABCDE}}$, \\ Кукух Вахьюдін Пратама ${ }^{2 B C D E}$, Девангга Юдхістіра ${ }^{2 B C D E}$
}

\author{
${ }^{1}$ Державний університет Джок'якарти \\ ${ }^{2}$ Інститут передової науки, техніки та освіти
}

Авторський вклад: А - дизайн дослідження; В - збір даних; C - статаналіз; D - підготовка рукопису; Е - збір коштів

Реферат. Стаття: 7 с., 14 табл., 1 рис., 18 джерел.

Мета дослідження - визначити рівень розуміння педагогічної компетентності студентів факультету спортивних наук Державного університету Джок'якарти, які спеціалізуються на фізичному вихованні, оздоровленні та рекреації, вступу 2016 року.

Матеріали та методи. Методом дослідження було опитування 3 кількісним описовим підходом. Зі 180 студентів, які спеціалізуються з фізичного виховання, вибрано 52 студенти за методом випадкового відбору. Інструментом дослідження був універсальний та надійний опитувальник. Методом аналізу даних був аналіз, представлений з використанням відсотка.

Результати. Отримані результати свідчать, що рівень розуміння педагогічної компетентності студентів факультету спортивних наук Державного університету Джок'якарти, які спеціалізуються на фізичному вихованні, оздоровленні та рекреації, вступу 2016 року, був «дуже низьким» 3,85\% (2 студенти), «низьким» 67,31\% (35 студентів), «середнім» 19,23\% (10 студентів), «високим» 9,62\% (5 студентів) i «дуже високим» $0 \%$ (0 студентів).

Висновки. За результатами дослідження можна зробити висновок, що рівень розуміння педагогічної компетентності студентів, які спеціалізуються на фізичному вихованні, $є$ низьким.

Ключові слова: рівень розуміння, педагогічна компетентність, студенти, фізичне виховання, оздоровлення та рекреація.

\section{Information about the authors:}

Hastuti Tri Ani: tri_anihastuti@uny.ac.id; https://orcid.org/0000-0002-1934-3025; Departement of Sports Science, Faculty of Sport Science, Yogyakarta State University, Jl. Colombo Yogyakarta No.1, Karang Malang, Caturtunggal, Kec. Depok, Kabupaten Sleman, Daerah Istimewa Yogyakarta 55281, Indonesia.

Jatmika Herka Maya: https://orcid.org/0000-0001-9741-2201; Departement of Sports Science, Faculty of Sport Science, Yogyakarta State University, Jl. Colombo Yogyakarta No.1, Karang Malang, Caturtunggal, Kec. Depok, Kabupaten Sleman, Daerah Istimewa Yogyakarta 55281, Indonesia.

Pratama Kukuh Wahyudin: kukuh.pratama@iasee.org; https://orcid.org/0000-0003-4518-6358; Institute of Advanced Science, Engineering, and Education (IASEE), Indonesia section: Tempelsari 004/035 Maguwoharjo, Depok Sleman,Yogyakarta 55282

Yudhistira Dewangga: dewangga@iasee.org; https://orcid.org/0000-0002-4194-1283; Institute of Advanced Science, Engineering, and Education (IASEE), Indonesia section: Tempelsari 004/035 Maguwoharjo, Depok Sleman, Yogyakarta 55282

Cite this article as: Hastuti, T. A., Jatmika, H. M., Pratama, K. W., \& Yudhistira, D. (2021). The Level of Understanding of Pedagogical Competence of Physical Education, Health and Recreation Students of Sports Science Faculty. Teoriâ ta Metodika Fizičnogo Vihovannâ [Physical Education Theory and Methodology], 21(4), 310-316. https://doi.org/10.17309/tmfv.2021.4.04

Received: 12.09.2021. Accepted: 16.10.2021. Published: 25.12.2021

This work is licensed under a Creative Commons Attribution 4.0 International License (http://creativecommons.org/licenses/by/4.0). 